\title{
Studies on the Kinetics of the Enzyme Sequence Mediating Arginine Synthesis in Saccharomyces cerevisiae
}

\author{
By F. HILGER, * M. CULOT, M. MINET, A. PIERARD, \\ M. GRENSON AND J. M. WIAME \\ Laboratoire de Microbiologie de l'Université Libre de Bruxelles, Institut de \\ Recherches du C.E.R.I.A., Bruxelles and Faculté des Sciences agronomiques de \\ l'Etat, Gembloux, Belgium
}

(Received 2I August 1972; revised I I October 1972)

SUMMARY

An analysis, by means of varying gene dosage at the tetraploid level, of the kinetic relationships which link the activity of individual enzymes to the functioning of the entire arginine biosynthetic pathway is presented. Tetraploid gene dosage series were prepared for each of the following gene-enzyme pairs: $\arg B$ coding for acetylglutamate kinase, $\arg F$ for ornithine transcarbamylase, $\arg H$ for argininosuccinase and cpaI coding for one of the two polypeptidic constituents of the argininepathway-specific carbamoylphosphate synthetase.

In each of these series, the growth rates remain constant whatever gene dose is present. When the dose of the $\arg B^{+}$and $\mathrm{cpaI}^{+}$alleles is decreased, the specific enzyme activity per wild-type allele increases, as a result of derepression. Consequently, the enzymes which are coded by these genes and located at the two entries of the arginine pathway are rate-limiting for the pathway.

In contrast, a decrease of the $\arg F^{+}$or $\arg H^{+}$alleles does not result in derepression, implying that the corresponding enzymes function far below their maximal capacities. Thus the activity of these enzymes is adapted to the metabolite flux imposed by the rate-limiting enzymes.

The interpretation of these observations with respect to the dominance relations is discussed. The wild-type alleles of $\arg F$ and $\arg H$ are dominant because of overproduction of the corresponding gene products. For the $\arg B$ and $c p a I$ genes, dominance results from a release of repression.

\section{INTRODUCTION}

While studying the regulatory behaviour of a specific metabolic pathway, there is always the problem of the actual catalytic activities in vivo of the individual enzymes of that pathway. The activities of the enzymes in their native milieu cannot be inferred from assays in vitro, as they are usually performed. The problem becomes really crucial if one is dealing with a metabolic system like that of arginine biosynthesis in Saccharomyces cerevisiae, i.e. a set of eight known reactions which are determined by I I structural genes which are largely scattered over the genome and the expression of which appears to lack coordination (Minet, 1971; Wiame, 1972).

First one may ask what is the rate-limiting step of the arginine biosynthetic sequence. One would expect the position of the pace-maker enzyme within the pathway to be at the starting point of the sequence, where it could operate as a valve determining the flux through the

* Present address: Chaire de Microbiologie,'Faculté des Sciences agronomiques de l'Etat, 5800 Gembloux, Belgique. 
entire circuit. If this enzyme had allosteric properties, allowing feed-back inhibition and possibly activation, it would allow an efficient regulation of the pathway. Second, what about the enzymes which do not mediate rate-limiting steps? To what extent are these enzymes in excess and, if the excess is large, what may be the physiological meaning of this?

It is the main topic of the present and another forthcoming paper to investigate these questions. The tool employed is gene dosage at the tetraploid level. For each structural gene of the arginine biosynthetic pathway (the arg-genes) a tetraploid gene dosage series is prepared and genetically checked according to the procedures described previously (Hilger, 1973). Each series comprizes four strains which, for a given allelic pair rrg $^{+} / \mathrm{arg}^{-}$, or $+1-$, represent the following gene doses: $4 / 4$ (wild-type, ++++ ), 3/4 (triplex, +++- ), 2/4 (duplex, ++ - ) and I/4 (simplex, +-- - ). If the mutant allele, $\mathrm{arg}^{-}$, is inactive, then the series provides a system of four gene concentrations decreasing linearly from the normal level (wild-type) to one-fourth of this (simplex). Measurement of the activities in vitro of particular enzymes of the arginine pathway through such systems should allow recognition of the kinetic roles of the individual enzymes in the sequence. Consider, for instance, a gene-enzyme pair determining a rate-limiting step of the arginine biosynthetic pathway. A decrease of the concentration of the gene will entail a lowering of the pool of the end product, arginine, and consequently a regulatory adjustment. The level of the enzyme considered, as well as that of the other arginine pathway enzymes, will show derepression, if they are under arginine control. In contrast, the concentration of a gene coding for a nonrate-limiting enzyme may decrease to a certain extent without resulting in derepression. The amount to which the non-rate-limiting enzyme may be decreased without derepression would be a good measure of the excess of this enzyme over that necessary for normal arginine synthesis.

This study deals with four enzymes, belonging to the three classes into which the arginine pathway enzymes of Saccharomyces cerevisiae are presently ranged (Minet, 197I; Wiame, 1972): (i) acetylglutamate kinase (EC. 2.7.2.3.) and ornithine transcarbamylase (EC. 2. I.3.3.) coded by the genes $\arg B$ and $\arg F$, respectively, and belonging to the class of enzymes which are repressible by exogenous arginine in wild-type and non-repressible in $\arg R$ mutants (Béchet, Grenson \& Wiame, 1970; Minet, I97I); (ii) the carbamoylphosphate synthetase involved in the arginine pathway and coded by the genes cpaI and cpaII (another carbamoylphosphate synthetase operates in the pyrimidine nucleotide synthesis and is coded by the gene $c p u$ ). This enzyme is repressible by exogenous arginine, insensitive to $\arg R$ mutations, but sensitive to cpaR and cpaIO mutations (Lacroute, Piérard, Grenson \& Wiame, 1965; Thuriaux, Ramos, Piérard, Grenson \& Wiame, 1972); (iii) argininosuccinase (EC. 4.3.2. I.), coded by the gene $\arg H$ and belonging to the class of enzymes which are insensitive to exogenous supplies of arginine.

\section{METHODS}

Strains and genetic methods. The primary, isogenic haploid strains used to build up the tetraploid series were the following: $\Sigma_{12} 278 \mathrm{~b}=\alpha$, wild-type; $3962 \mathrm{C}=\mathrm{a}$, wild type; $\mathrm{MG} 790=$ $\alpha, \arg B^{-} ; \mathrm{MG}_{7} 6=\alpha, \arg F^{-} ;{\mathrm{MG} 54^{2}}^{2} \alpha, \arg H^{-} ; 6028 \mathrm{~d}=\mathrm{a}, c p a I^{-}-2, c p u^{-}-2 ; \mathrm{BJIO}=\alpha$, $\arg R I^{-}-2$. The auxotrophic strains were selected for loss of enzymatic activities. More detailed informations about these strains and about the rules of nomenclature applied may be found in Grenson, Mousset, Wiame \& Béchet (1966), Béchet et al. (1970), Wiame (1972), Hilger (1973).

The tetraploid clones were developed and analysed according to the procedure outlined in the accompanying paper by Hilger. The following five tetraploid series were prepared: 
one $\arg B$ series (acetylglutamate kinase); two $\arg F$ series (ornithine transcarbamylase), one with the dose $4 / 4$ for the gene $\arg R I^{+}$, the other with $\arg R I^{+}$at dose $0 / 4$ (the synthesis of the arg-enzymes of class I (see Introduction) in the four strains of the latter series thus escapes repression by arginine); one $\arg H$ series (argininosuccinase); one cpaI series, the four members of which had the dose $0 / 4$ for $c p u^{-}$in order to avoid a possible interference of the product of $\mathrm{cpu}^{+}$(carbamoylphosphate synthetase integrated in the pyrimidine pathway) with the cpaI dosage effects to be measured; the deficiency resulting in this latter series from the elimination of $\mathrm{cpu}^{+}$was compensated for by supplementing the media with uracil ( $\mathrm{I} 00 \mu \mathrm{g} / \mathrm{ml}$ ).

All the clones used in this investigation had their genotypes confirmed by genetic analysis.

Media, conditions and measurement of growth. The gene dosage effects were measured on cells developing exponentially in liquid minimal medium no. I49 (Lacroute et al. I965; Grenson et al. I966). The members of the cpaI series were grown in the same medium supplemented with uracil ( $100 \mu \mathrm{g} / \mathrm{ml})$.

The incubation temperature was $29^{\circ} \mathrm{C}$ and the cultures were grown aerobically on a rotatory shaker; growth rates were established by measuring the absorbance at $660 \mathrm{~nm}$ in a Beckman spectrophotometer, model B.

\section{Enzyme assays}

Ornithine transcarbamylase was measured according to the method described by Ramos, Thuriaux, Wiame \& Béchet (1970).

Carbamoylphosphate synthetase was assayed by a modification of the method described by Lacroute et al. (1965). Cells grown under the conditions described above were resuspended

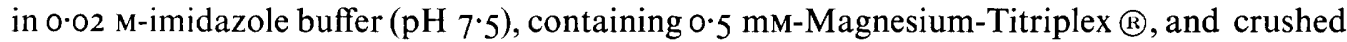
in a French pressure cell modified as described by Walters \& Stahly (I968). After centrifuging the extract at $25000 \mathrm{~g}$ for $5 \mathrm{~min}$, the supernatant fluid was dialysed by treatment on a column of Sephadex (1) G25 (pretreated with the same buffer). Carbamoylphosphate synthetase activities were determined shortly after the preparation of the extract in order to reduce the loss caused by the great instability of the enzyme. Carbamoylphosphate synthetase activity was assayed by converting $\left[{ }^{14} \mathrm{C}\right]$ bicarbonate to $\left[{ }^{14} \mathrm{C}\right]$ citrulline in the presence of an excess of ornithine transcarbamylase. Incubations were performed at $30{ }^{\circ} \mathrm{C}$ for $30 \mathrm{~min}$ and contained the following in a volume of $\mathrm{I} \mathrm{ml}$ : ATP, $10 \mu \mathrm{mol} ; \mathrm{MgCl}_{2}, \mathrm{I} 2 \mu \mathrm{mol}$; glutamine, Io $\mu \mathrm{mol} ;{ }^{14} \mathrm{C}-\mathrm{KHCO}_{3}$ (0.1 to $0.2 \mu \mathrm{Ci} / \mu \mathrm{mol}$ ), Io $\mu \mathrm{mol}$; ornithine, $5 \mu \mathrm{mol} ; \mathrm{KCl}$, Io $\mu \mathrm{mol}$; imidazole buffer ( $\mathrm{pH} 7.5$ ), $60 \mu \mathrm{mol}$; partially purified ornithine transcarbamylase from Escherichia coli, 100 to 200 units. The reaction was stopped by the addition of $\mathrm{I} \mathrm{ml}$ of cold $0.25 \mathrm{M}$-trichloroacetic acid and the precipitated proteins were removed by centrifugation. After elimination of the excess ${ }^{14} \mathrm{C}-\mathrm{KHCO}_{3}$ by air bubbling, a sample of $\mathrm{I} \mathrm{ml}$ of the incubated mixture was transferred to a polyethylene scintillation vial containing $10 \mathrm{ml}$ of scintillation cocktail (4 parts of Triton $\times 100,6$ parts of a solution containing $0.5 \% 2,5-$ diphenyloxazole and $10 \%$ naphthalene in reagent-grade dioxane). The samples were counted in a model LS IOo Beckman liquid scintillation spectrometer with an efficiency of $55 \%$.

Acetylglutamate kinase can be assayed easily by coupling the synthesis of phospho- $N$ acetylglutamate with its reduction into the corresponding semi-aldehyde, the concomitant disappearance of NADPH being measured. In this assay the dehydrogenase of the extract is used; it is in excess and increases co-ordinatively with the kinase activity, the genes coding for these two enzymes forming an operon which is also indicated by polarity mutations (Minet, Thuriaux, Grenson \& Wiame, unpublished results). However, that assay method is quantitatively uncertain due to an interfering NADPH oxidizing activity which is present 
in the extract. A more accurate but more tedious determination which implies a partial purification in order to eliminate an interfering reaction was developed. It proceeds by the determination of energy-rich phosphate by the method of Lipmann \& Tuttle (I945). The procedure was the following: $\mathrm{I} \cdot 5 \mathrm{~g}$ dry weight of cells (corresponding to $2.5 \mathrm{l}$ culture) were suspended in $20 \mathrm{ml} 0.25 \mathrm{M}$-tris- $\mathrm{HCl}$ buffer (pH 7.5) containing $0.5 \mathrm{~mm}$-dithiothreitol (DTT) and crushed in a French pressure cell modified according to Walters \& Stahly ( 1968 ). The supernatant of the extract was brought to $35 \mathrm{ml}$ with buffer and precipitated with streptomycin sulphate (final concentration $\mathrm{r} \%$ ). After $15 \mathrm{~min}$ standing, the precipitate was removed and the supernatant precipitated at $50 \%$ saturation of ammonium sulphate. The precipitate was discarded and ammonium sulphate was added to $60 \%$ saturation. The precipitate which contained the enzyme was dissolved in $0.6 \mathrm{ml} 0.05$ tris- $\mathrm{HCl}$ buffer $(\mathrm{pH} 7.5)$ containing 0.5 mM-DTT, and dialysed by filtration through a column containing $3 \mathrm{~g}$ Sephadex (B) G25. The solution obtained, containing Io to $15 \mathrm{mg}$ protein $/ \mathrm{ml}$, was used for the kinase assay. The assay mixture (prepared at $\mathrm{O}^{\circ} \mathrm{C}$ ) contained: $0.325 \mathrm{ml}$ of extract plus $0.05 \mathrm{M}$-tris- $\mathrm{HCl}$

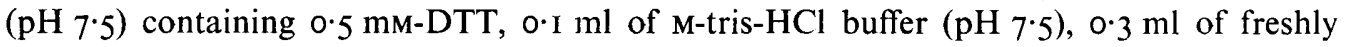
prepared $3.3 \mathrm{M}$-hydroxylamine- $\mathrm{HCl}\left(\mathrm{pH}_{7.5}\right), 0.075 \mathrm{ml}$ of $0.2 \mathrm{M}-\mathrm{ATP}(\mathrm{pH} \mathrm{7.5}), 0 . \mathrm{I} \mathrm{ml} \mathrm{of}$ $0.3 \mathrm{M}-\mathrm{MgCl}_{2}$ and $0 . \mathrm{I} \mathrm{ml}$ of $0.8 \mathrm{M}-\mathrm{N}$ - $\alpha$-acetylglutamate $(\mathrm{pH} 7.5)$. The reaction was started by transfer to $30{ }^{\circ} \mathrm{C}$ and stopped after 90 min by addition of $0.33 \mathrm{ml}$ of $6 \mathrm{~N}-\mathrm{HCl}$ and $0.33 \mathrm{ml}$ of $12 \%$ trichloracetic acid. After removal of the precipitate, $0.33 \mathrm{ml}$ of $5 \% \mathrm{FeCl}_{3} .6 \mathrm{H}_{2} \mathrm{O}$ in $\mathrm{HCl} \mathrm{O}^{\mathrm{I}} \mathrm{N}$ were added. The colour was developed for $5 \mathrm{~min}$ and read at $5 \mathrm{IO} \mathrm{nm}$, acetylphosphate being used as a standard. The $K_{m}$ of the enzyme for acetylglutamate is $3 \mathrm{~mm}$. Arginine inhibits the activity at $80 \%$ with a $K_{i}$ of $0.05 \mathrm{M}$.

Argininosuccinate synthetase. A $0.15 \mathrm{~g}$ dry weight portion of cells (corresponding to $250 \mathrm{ml}$ culture) was suspended in $3 \mathrm{ml} 0.05 \mathrm{M}$-potassium phosphate buffer, $\mathrm{pH} 7.5$, sonicated for $8 \mathrm{~min}$ in a MSE-Mullard sonic oscillator. The supernatant of the centrifuged extract was dialysed twice for I $\mathrm{h}$ against I mM-potassium phosphate buffer $(\mathrm{pH} \mathrm{7.5)}$. The activity was determined by measuring the disappearance of citrulline in $30 \mathrm{~min}$ at $30{ }^{\circ} \mathrm{C}$ in a reaction mixture containing: $0.65 \mathrm{ml}$ of extract (about $6 \mathrm{mg}$ of proteins $/ \mathrm{ml}$ ) plus $0.05 \mathrm{M}$-phosphate

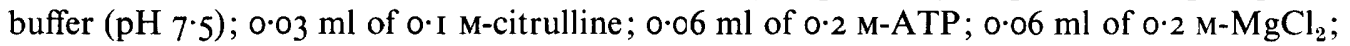
$0.2 \mathrm{ml}$ of $0.05 \mathrm{M}-\mathrm{L}$-aspartate. The reaction was stopped by addition of $\mathrm{I} \mathrm{ml}$ of $6 \%$ trichloroacetic acid and the precipitated proteins discarded by centrifuging. Citrulline was estimated by the method of Archibald (1944). A control containing no aspartate was subtracted. As the relative disappearance of citrulline decreases with the amount of extract incubated, the activities measured were extrapolated to low concentrations of extract.

Argininosuccinase was assayed by coupling with arginase and estimating the urea formed. A culture of $100 \mathrm{ml}(0.6 \mathrm{mg}$ dry weight $/ \mathrm{ml})$ was permeabilized by addition of $2.5 \mathrm{ml}$ of a mixture of nine parts of a fresh solution of nystatine $(0.3 \%$ in methanol) and one part of cycloheximide solution ( $0.08 \%$ in water). Cycloheximide was used in order to inhibit protein synthesis. The permeabilization was carried on at $30^{\circ} \mathrm{C}$ with shaking. After $30 \mathrm{~min}$, the cells were cooled, collected by centrifugation and resuspended in $10 \mathrm{ml} 0.02 \mathrm{M}$-phosphate buffer $(\mathrm{pH} 7 \cdot 5)$. An argininosuccinate solution was prepared by dissolving $75 \mathrm{mg}$ barium argininosuccinate in $\mathrm{I} \cdot 5 \mathrm{ml} \mathrm{H}_{2} \mathrm{O}$, adding $\mathrm{I} \mathrm{ml} 0.5 \mathrm{M}^{-} \mathrm{K}_{2} \mathrm{SO}_{4}$ and removing the precipitated $\mathrm{BaSO}_{4}$. A mixture of 5 vol. of this solution plus 2 vol. of I M-potassium phosphate $(\mathrm{pH} 7 \cdot 5)$ and I vol. of I \% arginase (Worthington) was prepared. A $0.2 \mathrm{ml}$ sample of the latter mixture was incubated for $30 \mathrm{~min}$ at $37^{\circ} \mathrm{C}$ in presence of $0.7 \mathrm{ml}$ of the permeabilized cells suspension and the reaction stopped with $\mathrm{I} \mathrm{ml}$ of $7.5 \%$ trichloroacetic acid. After centrifuging, samples of the supernatant were assayed for urea by the method of Archibald (1945). The $K_{m}$ for argininosuccinate is $3.5 \mathrm{~mm}$. 
Table I. The dosage effects of arg $F^{+}$alleles in repressed $\left(\arg R^{+}\right)$and derepressed $\left(\arg R^{-}\right)$ clones on generation time and the levels of ornithine transcarbamylase and argininosuccinate synthetase

\begin{tabular}{|c|c|}
\hline $\begin{array}{c}\arg R^{-} \\
\text {dose }\end{array}$ & $\begin{array}{l}\text { Dosage effects: generation time and } \\
\text { specific enzyme activities }\end{array}$ \\
\hline $4 / 4$ & $\begin{array}{l}\text { Generation time (min) } \\
\text { Ornithine transcarbamylase activity } \\
\text { total } \\
\text { per } \arg F^{+} \text {allele } \\
\text { Argininosuccinate synthetase activity }\end{array}$ \\
\hline $0 / 4$ & $\begin{array}{l}\text { Generation time (min) } \\
\text { Ornithine transcarbamylase activity } \\
\text { total } \\
\text { per } \arg F^{+} \text {allele }\end{array}$ \\
\hline
\end{tabular}

\begin{tabular}{cccc}
\multicolumn{4}{c}{$\arg F^{+}$dose } \\
\cline { 2 - 4 } 102 & $3 / 4$ & $2 / 4$ & $1 / 4$ \\
& 112 & 104 & 96 \\
25.4 & 20.5 & $13 \cdot 1$ & $7 \cdot 1$ \\
6.3 & 6.8 & 6.5 & $7 \cdot 1$ \\
0.56 & - & - & 0.55 \\
96 & 97 & 101 & 91 \\
& & & \\
54.4 & 38.2 & 27.3 & 14.6 \\
13.6 & 12.7 & 13.6 & 14.6
\end{tabular}

Protein determinations were performed by the method of Folin and Ciocalteu (Layne, I957) using bovine serum albumin as standard.

An enzyme unit is defined as the amount that catalyses the transformation of $\mathrm{I} \mu \mathrm{mol}$ substrate in I h. Specific activities are enzyme units $/ \mathrm{mg}$ of protein.

\section{RESULTS}

The $\arg F$ (ornithine transcarbamylase) dosage effects

The dosage effects measured through the two parallel $\arg F$ series, one composed of strains repressible by arginine ( $4 / 4$ for $\arg R I^{+}$), the other of members insensitive to arginine (o/4 for $\arg R I^{+}$), show that the growth rate remains unaffected at the lower $\arg F$ doses and that the specific activity of ornithine transcarbamylase is proportional to the number of wild-type $\arg F^{+}$alleles, i.e. the specific activity of ornithine transcarbamylase/wild-type allele remains constant through each series of gene doses. The results obtained for the two parallel series are in excellent agreement and illustrate what is known about the effects of the $\arg R$ mutations (Béchet et al. 1970): the levels of ornithine transcarbamylase are about twice the normal in the derepressed $\arg R^{-}$strains (Table I; Fig. I).

The level of ornithine transcarbamylase is correlated with the arginine pool (Ramos et al. I970), and this enzyme can be lowered to one-fourth of its normal value without any change in the arginine pool. This is confirmed by the levels of argininosuccinate synthetase in these tetraploids. The level of this enzyme which is under arginine control remains unaffected as the $\arg F$ dose is decreased from $4 / 4$ to $1 / 4$.

\section{The argH (argininosuccinase) dosage effects}

The relation of the generation time and the enzyme levels to the concentration of $\arg H$ is similar to that for $\arg F$. The enzyme coded by $\arg H$ decreases linearly with the $\arg H$ dose, while ornithine transcarbamylase, which is used here as an indicator of the regulation of arginine synthesis, remains at the same level (Table 2; Fig. 2).

\section{The $\arg B$ (acetylglutamate kinase) and cpaI (carbamoylphosphate synthetase) dosage effects}

Again the growth rate is unaffected by decreasing the gene dose to one-fourth (Table 2; Fig. 3, 4). However, the effects on the enzyme levels are different from those observed for the 


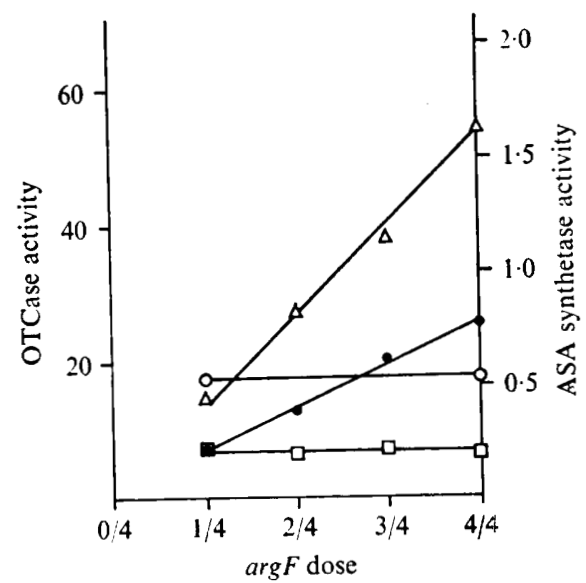

Fig. 1

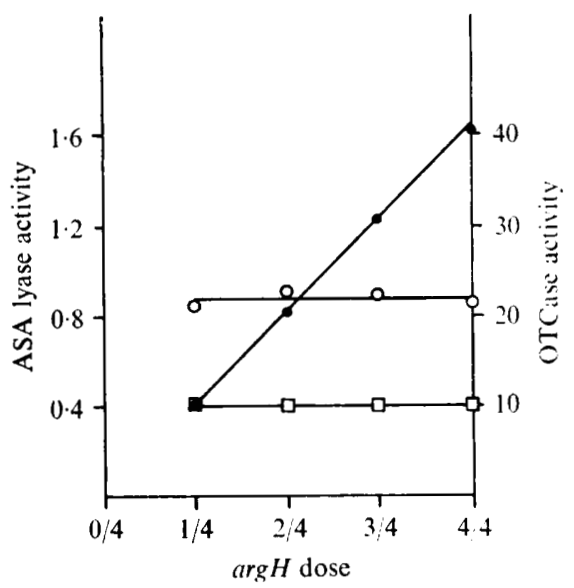

Fig. 2

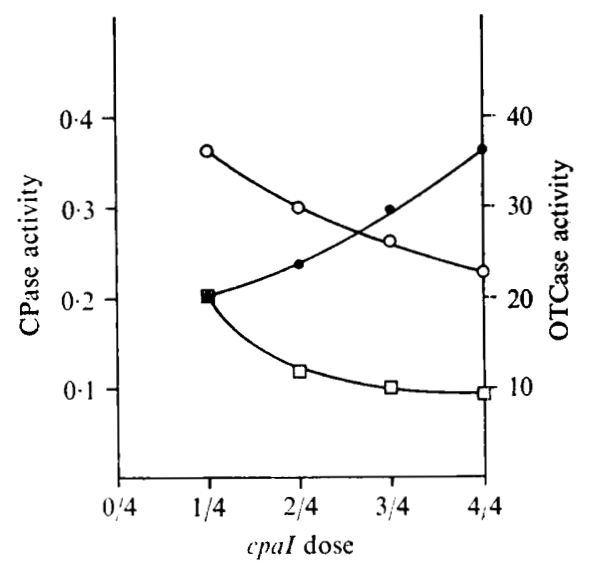

Fig. 3

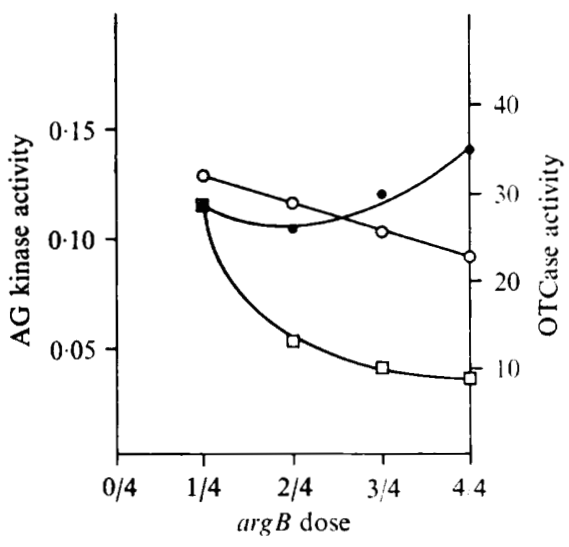

Fig 4

Fig. I. Dosage effects of the $\arg F^{+}$allele on the levels of ornithine transcarbamylase (OTCase) and argininosuccinate synthetase (ASA synthetase). Enzyme levels are expressed as specific activities (units/mg protein). -1 , Total specific activity of OTCase; $\square-\square$, specific activity of OTCase per $\arg F^{+}$allele; $\bigcirc-O$, total specific activity of ASA synthetase; $\triangle-\triangle$, total specific activity of OTCase in an insensitive series (dose $0 / 4$ for $\arg R I$ ).

Fig. 2. Dosage effects of the $\arg \mathrm{H}^{+}$allele on the levels of argininosuccinase (ASA lyase) and ornithine transcarbamylase (OTCase). Enzyme levels are expressed as specific activities (units/mg protein). - - T - Total specific activity of ASA lyase; $-\square-\square-$, specific activity of ASA lyase per $\arg H^{+}$allele; $-\mathrm{O}-\mathrm{O}-$, total activity of OTCase.

Fig. 3. Dosage effects of the $\mathrm{cpaI}^{+}$allele on the levels of the carbamoylphosphate synthetase (CPase) and ornithine transcarbamylase (OTCase). Enzyme levels are expressed as specific activities (units! mg protein). - - - Total specific activity of CPase. $-\square-\square-$, specific activity of CPase per $\mathrm{cpaI}^{+}$allele. $-\mathrm{O}-\mathrm{O}_{--}^{-}$, total activity of OTCase.

Fig. 4. Dosage effects of the $\arg B^{+}$allele on the levels of acetylglutamate kinase (AG kinase) and ornithine transcarbamylase (OTCase). Enzyme levels are expressed as specific activities (units/mg protein). - - - Total specific activity of AG kinase; $-\square-\square-$, specific activity of AG kinase per $\arg B^{+}$allele; - $-\mathrm{O}-$, total activity of OTCase. 
Table 2. The effect of different doses of $\arg H^{+}, \mathrm{cpaI}^{+}$and $\arg \mathrm{B}^{+}$on the levels of their products: argininosuccinase, carybamoylphosphate synthetase $A$ and $N$-acetylglutamate kinase respectively, on the level of ornithine transcarbamylase and on the generation time

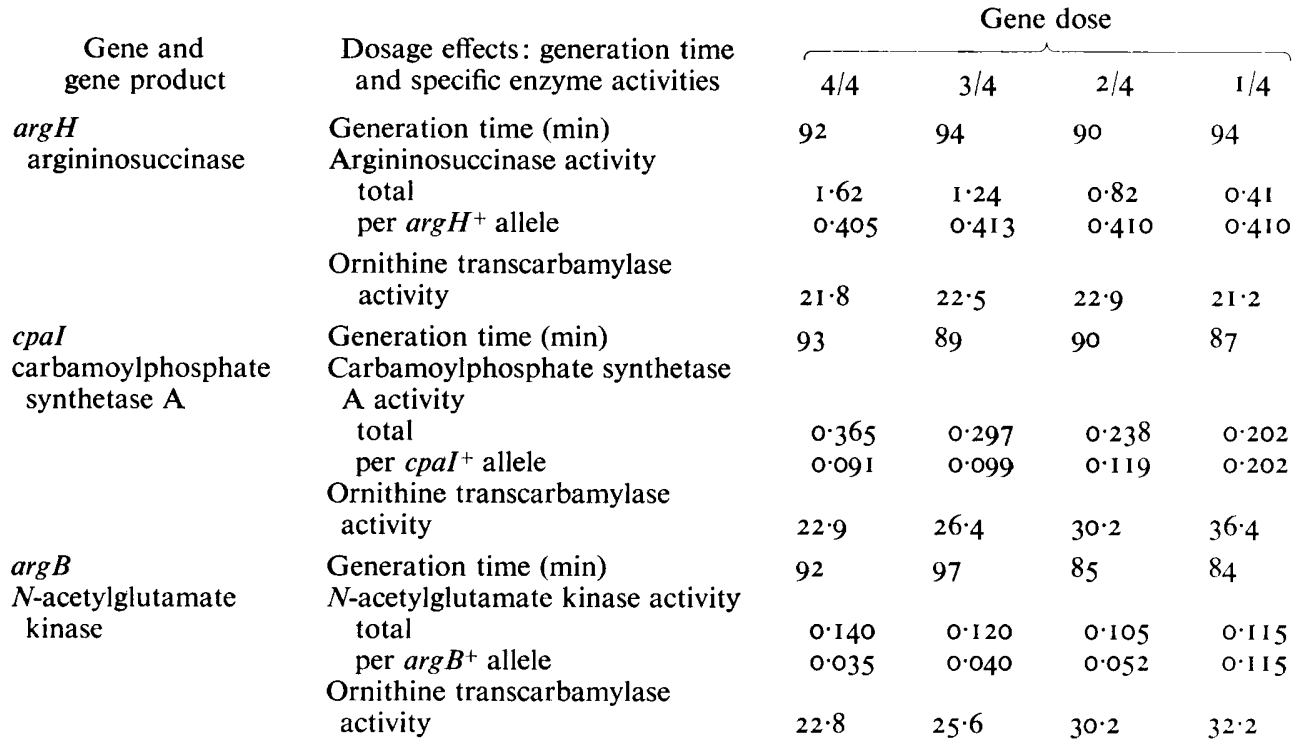

previous enzymes. This time, the relations of the total specific activities of the enzymes to the concentrations of their respective wild-type alleles are not simply proportional. The specific activity/wild-type allele increases as the gene dose decreases. At the same time the activity of the control enzyme, ornithine transcarbamylase, increases. This clearly indicates derepression. The derepression is immediate in both instances, since lowering the gene doses by $\mathrm{I} / 4$ (doses $3 / 4$ ) results in significant increase of the ornithine transcarbamylase level.

\section{DISCUSSION}

The data show that for the four genes considered the growth rate remains constant when the gene doses are varied. The four mutations $\arg B^{-}, \arg F^{-}, \arg H^{-}$and $c p a I^{-}$, selected for complete loss of the respective enzyme activities, are completely recessive. At the molecular level, this situation may be explained in three ways: (i) the wild-type cell, when grown on minimal medium, may overproduce enzymes with respect to the arginine needs of the cell; (ii) derepression of enzyme synthesis might provide a gene dosage compensation mechanism; (iii) the products of the mutated alleles might recover a certain activity when associated with the normal product by the formation of active hybrid enzymes (Zimmermann, Schmiedt \& Ten Berge, 1969).

Examination of the enzyme data will help in settling this question. Altering the gene dosage can result in two distinct patterns of enzyme activity. First, simple additivity of the enzyme levels as shown by $\arg F$ and $\arg H$. This relation is analogous to those found for iso-I-cytochrome $c$ in fully induced yeast cells (Slonimski, Archer, Péré, Sels \& Somlo, I965) and for tryptophan synthetase, which seems constitutive in yeast (Ciferri, Sora \& Tiboni, 1969). In our case, the output of the metabolic pathway does not change after lowering the levels of the enzymes to one-fourth. This indicates that the two enzymes are not rate- 
limiting and their level in vivo is at least four times greater than that necessary for normal arginine synthesis. A similar situation is suggested for argininosuccinase in Neurospora crassa (Donachie, I964).

The second gene dosage pattern is of a more elaborate type. The activities of the $\arg B^{+}$ and $\mathrm{cpaI}^{+}$alleles increase as the gene doses decrease. This results from derepression of the synthesis of the arginine pathway enzymes, as shown by the control enzyme ornithine transcarbamylase. A gene dosage relation of this kind has been found in yeast by Nelson \& Douglas (I963) for the gene-enzyme pair gaI-galactokinase (contrary to the statement by Hartwell, 1970). The enzyme data for the various $\arg B^{+}$and $c p a I^{+}$dosages suggest that carbamoylphosphate synthetase and acetylglutamate kinase are rate-limiting enzymes for arginine synthesis in wild-type yeast grown on minimal medium.

The two distinct gene dosage patterns observed imply two distinct kinetic situations, in vivo, with respect to the enzymes involved. Concerning the $\arg F$ and $\arg H$ gene dosages, the kinetic situation may be expected to be the following: ornithine transcarbamylase and argininosuccinase must be far from saturation by their respective substrates, when wild-type yeast cells are grown exponentially on minimal medium; then lowering the levels of each one of the two enzymes considered, by decreasing the corresponding gene concentrations, results in a shift of the substrate pools to higher values; this shift entails an acceleration of the reactions catalysed by ornithine transcarbamylase or argininosuccinase, so that the net flow through the respective reaction steps, and hence the arginine pool, remain approximately constant. In the case of the $\arg B$ and $c p a I$ genes the kinetic behaviour is completely different: a reduction of the dose of one of these genes results in derepression of the corresponding enzyme as well as in gratuitous derepression of another enzyme of the pathway, ornithine transcarbamylase, which was previously shown as non-limiting. Such a behaviour could result from one of the two following situations: (i) the enzyme of which the gene dose is varied functions at its maximal rate; (ii) the cellular concentration of the substrates of this enzyme cannot undergo substantial variations. The latter situation is likely to exist for the enzymes considered here, carbamoylphosphate synthetase and acetylglutamate kinase, in view of the fact that they catalyse the first specific steps of the pathway and, consequently, use substrates, such as ATP, glutamine or $\mathrm{HCO}_{3}^{-}$, which are of general use in the cell.

The pacemaker enzymes acetylglutamate kinase and carbamoylphosphate synthetase are located precisely at the two entries of the arginine biosynthetic pathway. Furthermore, these two enzymes are subjected to feedback controls by arginine-carbamoylphosphate synthetase to repression and acetylglutamate kinase to repression and inhibition (De Deken, I962; Minet, I97I). Consequently, the flow of intermediates leading to arginine is governed at the starting points of the reaction sequence and the enzymes located beyond these entries function at the velocity imposed upon them by the pacemakers. This state of things is obviously favourable for the economy of the cell. It means, however, that all enzymes beyond the entries function below their capacities, which might be interpreted as an uneconomic overproduction of enzymes. It also means, if the enzymes have the appropriate $K_{m}$ values, that labile intermediates can be present at extremely low concentrations in the cell. It happens that carbamoylphosphate, one of the substrates of ornithine transcarbamylase, and argininosuccinate, the substrate of argininosuccinase, are unstable compounds.

This investigation was supported by a grant from the 'Fonds de la Recherche Fondamentale Collective'. Two of us, M. M. and M. C., were 'boursiers' of the 'Institut pour l'Encouragement de la Recherche Scientifique dans l'Industrie et l'Agriculture'. 


\section{REFERENCES}

ARCHIBALD, R. M. (1944). Determination of citrulline and allantoin and demonstration of citrulline in blood plasma. Journal of Biological Chemistry 156, 121 -142.

ARChibald, R. M. (1945). Colorimetric determination of urea. Journal of Biological Chemistry 157, 507-5 I 8.

BÉCHET, J., Grenson, M. \& WiAmE, J. M. (1970). Mutations affecting the repressibility of arginine biosynthetic enzymes in Saccharomyces cerevisiae. European Journal of Biochemistry 12, 3I-39.

CifERri, O., Sora, S. \& TiBoni, O. (1969). Effect of gene dosage on tryptophan synthetase activity in Saccharomyces cerevisiae. Genetics 6r, 567-576.

De Deken, R. H. (1962). Pathway of arginine biosynthesis in yeast. Biochemical and Biophysical Research Communications 8, 462-466.

DoNACHIE, W. D. (1964). The regulation of pyrimidine biosynthesis in Neurospora crassa. II. Heterocaryons and the role of the regulatory mechanisms. Biochimica et biophysica acta 82, 293-302.

Grenson, M., Mousset, M., WiAme, J. M. \& BéChet, J. (1966). Multiplicity of the amino acid permeases in Saccharomyces cerevisiae. Biochimica et biophysica acta 127, 325-338.

Hartwell, L. H. (1970). Biochemical genetics of yeast. Annual Review of Genetics 4, 373-396.

HILGER, F. (1973). Construction and analysis of tetraploid yeast sets for gene dosage studies. Journal of General Microbiology 75, 23-3I.

Lacroute, F., Piérard, A., Grenson, M. \& Wiame, J. M. (1965). The biosynthesis of carbamoylphosphate in Saccharomyces cerevisiae. Journal of General Microbiology 40, 127-142.

LAYNE, E. (1957). Spectrophotometric and turbidimetric methods for measuring proteins. In Methods in Enzymology, vol. III, pp. 447-454. Edited by S. P. Colowick and N. O. Kaplan. New York: Academic Press.

LipmanN, F. \& Tuttle, L. C. (1945). A specific micromethod for the determination of acylphosphate. Journal of Biological Chemistry 159, 2 I-32.

MinET, M. (197I). La biosynthèse de l'arginine chez Saccharomyces cerevisiae: contribution à l'étude de son déterminisme génétique et de sa régulation. Thèse de doctorat, Université Libre de Bruxelles.

Nelson, N. M. \& Douglas, H. C. (1963). Gene dosage and galactose utilization by Saccharomyces tetraploids. Genetics 48, I 585-159I.

Ramos, F., Thuriaux, P., Wiame, J. M. \& Béchet, J. (1970). The participation of ornithine and citrulline in the regulation of arginine metabolism in Saccharomyces cerevisiae. European Journal of Biochemistry 12, $40-47$.

Slonimski, P. P., Archer, R., Péré, G., Sels, A. \& Somlo, M. (1965). In Mécanismes de régulation des activités cellulaires chez les microorganismes, pp. 435-46I. Paris: Editions du Centre National de la Recherche Scientifique.

Thuriaux, P., Ramos, F., Piérard, A., Grenson, M. \& Wiame, J. M. (1972). The regulation of the carbamoylphosphate synthetase belonging to the arginine biosynthetic pathway of Saccharomyces cerevisiae. Journal of Molecular Biology 67, 277-287.

Walters, J. R. \& STAhLY, D. P. (1968). Modification of the valve of the French pressure cell. Applied Microbiology $16,1605-1608$.

Wiame, J. M. (1972). The regulation of arginine metabolism in Saccharomyces cerevisiae: exclusion mechanism. In Current Topics in Cellular Regulation, vol. Iv, pp. I-38. Edited by Horecker and Stadtman. New York: Academic Press.

Zimmermann, F. K., Schmiedt, I. \& Ten Berge, A. M. A. (1969). Dominance and recessiveness at the protein level in mutant $\mathrm{x}$ wild-type crosses in Saccharomyces cerevisiae. Molecular and General Genetics 104, $32 \mathrm{I}-330$. 